Fahrani Yulzain, Jumiatil Efektivitas UPTD Balai Latihan Kerja (BLK) dalam Meningkatkan Kualitas Tenaga Kerja di UPTD BLK Kabupaten Padang Pariaman

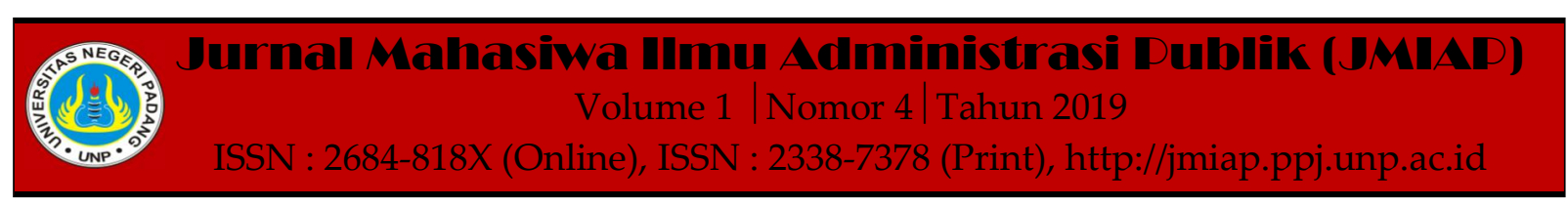

\title{
EFEKTIVITAS UPTD BALAI LATIHAN KERJA (BLK) DALAM MENINGKATKAN KUALITAS TENAGA KERJA DI UPTD BLK KABUPATEN PADANG PARIAMAN
}

\author{
Fahrani Yulzain ${ }^{1(a)}$, Jumiati $^{2(b)}$ \\ ${ }^{1}$ Jurusan Ilmu Administrasi Negara, Universitas Negeri Padang \\ ${ }^{2}$ Jurusan Ilmu Administrasi Negara, Universitas Negeri Padang \\ a)faraniyulzain3@gmail.com, ${ }^{b)}$ jumiati.upik1962@gmail.com
}

\begin{abstract}
This study aims to determine the effectiveness of UPTD Balai Latihan Kerja (BLK) in improving the quality of labor and the factors that influence the effectiveness of UPTD Balai Latihan Kerja $(B L K)$ in improving the quality of the workforce at UPTD Balai Latihan Kerja (BLK) Kabupaten Padang Pariaman. Type of research is qualitative research with descriptive methods. The data source used in this study is primary data and secondary data. Techniques for collecting data on observation, interviews, and documentation. Test the validity of the data is using the source triangulation technique. The results of study showed that UPTD Balai Latihan Kerja (BLK) Kabupaten Padang Pariaman was quite effective in improving the quality of labor and the factors that influenced the effectiveness UPTD Balai Latihan Kerja (BLK) Kabupaten Padang Pariaman in improving the quality of labor were organizational characteristics, environmental characteristics, worker characteristics, and management policies and practices
\end{abstract}

Keywords : Effectiveness, Labor, Quality, the Regional Government System

Corresponding author. Email.faraniyulzain3@gmail.com,jumiati.upik1962@gmail.com

How to cite this article. Yulzain, F \& Jumiati. (2019). Efektivitas UPTD Balai Latihan Kerja (BLK) dalam Meningkatkan Kualitas Tenaga Kerja di UPTD BLK Kabupaten Padang Pariaman. Jurnal Mahasiwa Ilmu Administrasi Publik (JMIAP) Jurusan Ilmu Administrasi Negara Fakultas Ilmu Sosial Universitas Negeri Padang, Volume 1 (4), Hal. 12-19.

http://jmiap.ppj.unp.ac.id

ISSN : 2684-818X (Online), ISSN : 2338-7378 (Print)

Copyright $(2019$. Published by Pusat Kajian-Pemberdayaan dan Pelayanan Masyarakat (PK-P2M) FIS UNP Padang 


\section{PENDAHULUAN}

Masalah ketenagakerjaan di Indonesia menjadi masalah yang tidak kunjung usai dan menjadi penghambat bagi pembangunan di Indonesia, hal ini dikarenakan masih rendahnya kualitas tenaga kerja yang terdapat di Indonesia. Sedangkan tenaga kerja itu sendiriberperan penting dalam melakukan kegiatan pembangunan, dimana tenaga kerja yang memiliki kualitas yang bagus akan mampu mendukung pembangunan di suatu negara. Begitu juga dengan masalah ketenagakerjaan di Sumatera Barat khususnya Kabupaten Padang Pariaman yang cukup memprihatinkan yang ditandai dengan tingginya jumlah pengangguran, pendapatan masyarakat yang rendah dan kurang merata. Oleh karena itu untuk mengatasi permasalahan ketenagakerjaan ini, Kementerian Tenaga Kerja membentuk BLK yang tersebar diseluruh wilayah di Indonesia salah satunya Balai Latihan Kerja (BLK) di Kabupaten Padang Pariaman. Balai Latihan Kerja (BLK) merupakan sebuah wadah untuk melakukan kegiatan pelatihan bagi peserta yang mengikuti pelatihan sehingga peserta mampu menguasai suatu kompetensi kerja tertentu yang dapat dijadikan bekal bagi dirinya untuk memasuki pasar kerja.

Namun pada kenyataannya pada UPTD BLK Kabupaten Padang Pariaman ini masih terdapat permasalahan-permasalahan seperti kurangnya jumlah instruktur, dimana dari 8 (delapan) kejuruan, hanya ada 10 (sepuluh) orang instruktur, bahkan ada 1 (satu) kejuruan yang tidak memiliki instruktur. Permasalahan selanjutnya kurangnya sarana dan prasarana, yang ditandai dengan sarana yang digunakan merupakan sarana yang sudah lama dan adanya kekurangan sarana untuk beberapa kejuruan. Dan permasalahan selanjutnya yaitu masih rendahnya kualitas peserta pelatihan setelah melakukan pelatihan, hal ini dapat dilihat dari hasil uji kompetensi yang dilakukan pada UPTD BLK setelah mengikuti pelatihan kerja, dimana masih terdapat beberapa peserta pelatihan yang tidak lulus uji kompetensi yang dilakukan pada masing-masing sub kejuruan. Setiap sub kejuruan terdiri dari 16 orang peserta pelatihan, dan pada saat mengikuti uji kompetensi hanya terdapat 12 sampai 14 orang yang lulus uji kompetensi ini. Oleh karena itu penulis merasa tertarik untuk melakukan penelitian tentang efektivitas UPTD BLK dalam meningkatkan kualitas tenaga kerja dan faktor-faktor yang mempengaruhi keefektifan UPTD BLK dalam meningkatkan kualitas tenaga kerja dengan studi di UPTD BLK Kabupaten Padang Pariaman.

\section{TINJAUAN PUSTAKA \\ Konsep Efektivitas}

Menurut Ritno H. Rondonuwu dkk (Rondonuwu, 2015) efektivitas adalah pencapaian hasil dari pelaksanaan program yang dibuat dengan target yang telah ditetapkan. Efektivitas juga dapat diartikan sebagai perbandingan antara outcome dengan output. Semakin besar peranan output terhadap pencapaian suatu tujuan, maka suatu organisasi atau program dapat dikatakan efektif. Maka untuk melihat efektivitas UPTD BLK, penulis menggunakan 8 (delapan) indikator efektivitas yang dikemukakan oleh Sondang P. Siagian (Siagian, 1984)yang terdiri dari adanya kejelasan tujuan dicapai yang akan dicapai, adanya kejelasan strategi dalam upaya mencapai tujuan, melakukan analisa dan perumusan kebijaksanaan yang mantap, membuat perencanaan yang matang, menyusun program secara tepat, menyediakan sarana dan prasarana kerja, pelaksanaan yang bersifat efektif dan efisien, dan melakukan pengawasan dan pengendalian yang bersifat mendidik.

\section{Konsep UPTD Balai Latihan Kerja (BLK)}

Menurut Peraturan Menteri Dalam Negeri Nomor 12 Tahun 2017 yang menjelaskan tentang Pembentukan Cabang Dinas dan Unit Pelaksana Teknis Daerah, Unit Pelaksana Teknis Daerah (UPTD) 
merupakan suatu organisasi yang melaksanakan kegiatan yang bersifat teknis operasional dankegiatan yang bersifat teknis penunjang tertentu pada suatu dinas. Kegiatan teknis operasional bertugas untuk melakukan kegiatan teknis tertentu yang berhubungan dengan pemberian pelayanan kepada masyarakat. Sedangkan kegiatan teknis penunjang bertugas untuk melaksanakan kegiatan teknis yang bertujuan untuk mendukung pelaksanaan tugas dari organanisasi induknya.Menurut Peraturan Menteri Tenaga Kerja Nomor 8 Tahun 2017 yang menjelaskan tentang Balai Latihan Kerja yang disingkat dengan BLK, merupakan suatu wadahuntuk menyelenggarakan proses kegiatan pelatihan kerja bagi peserta yang mengikuti pelatihan kerja sehingga dengan adanya pelatihan ini peserta dapat menguasai suatu jenis kompetensi kerja tertentu yang nantinya dapat dijadikan bekal bagi dirinya untuk memasuki pasar kerja atau berwirausaha sendiri.

Untuk Kabupaten Padang Pariaman BLK disebut dengan UPTD BLK yang pada saat ini berada dibawah naungan Dinas Perdagangan, Tenaga Kerja Koperasi dan Usaha Kecil Menengah Kabupaten Padang Pariaman. Dimana sejak adanya otonomi daerah, dilakukan perubahan sistem pembinaan Balai Latihan Kerja yang sebelumnya bersifat sentralisasi dengan berlandaskan pada undang-undang nomor 22 tahun 1999 tentang pemerintahan daerah, kemudian diubah menjadi desentralisasi dengan berlandaskan pada undang-undang nomor 32 tahun 2004 yang kemudian diubah menjadi undang-undang nomor 23 tahun 2014. Dengan adanya perubahan sistem pembinaan BLK ini mengakibatkan hampir seluruh BLK yang awalnya dikelola oleh pemerintah pusat, pada saat ini diserahkan pengelolaannya kepada pemerintah daerah. Dengan adanya perubahan ini beban pembiayaan operasional pada BLK, biaya pelatihan kerja serta perawatannya menjadi beban Pemerintah daerah.
Menurut Peraturan Bupati Padang Pariaman Nomor 47 Tahun 2017 yang membahas tentang Pembentukan UPTD pada Dinas Perdagangan, Tenaga Kerja Koperasi dan Usaha Kecil Menengah dikatakan bahwa Dinas Perdagangan, Tenaga Kerja Koperasi Dan Usaha Kecil Menengah adalah perangkat daerah yang bertugas untuk melaksanakan urusan pemerintahanyang berkaitan dengan Perdagangan, Tenaga Kerja Koperasi Dan Usaha Kecil Menengah.

\section{Konsep Pelatihan Kerja}

Menurut Undang-undang Republik Indonesia Nomor 13 tahun 2003 yang menjelaskan tentang Ketenagakerjaan pelatihan kerja merupakan suatu kegiatan yang dilakukan untuk meningkatkan kompetensi kerja, sikap, dan etos kerja peserta pelatihan pada suatu keahlian tertentu sesuai dengan kualifikasi pekerjaan yang ditekuni. Sedangkan menurut Abdurrahmat Fathoni (Fatoni, 2006) pelatihan merupakan usaha untuk berbagi pengetahuan dan keterampilan kepada peserta pelatihan semaksimal mungkin sehingga peserta pelatihan dapat menerima dan mempraktekkan ilmunya pada saat bekerja. Sedangkan menurut Clark (1991) dalam Suparno (Widodo, 2018) pelatihan merupakan usaha untuk membuat suatu perubahan pada pengetahuan, sikap, dan keterampilan. Pelatihan juga dapat diartikan sebagai suatu proses pembelajaran yang berorientasi pada perubahan, sehingga dalam hal iniinstruktur atau pelatih memiliki peranan sangat penting dalam menciptaan perubahan pada peserta pelatihan.

\section{Konsep Kualitas Tenaga Kerja}

Menurut kamus besar Bahasa Indonesia kualitas adalah tingkat yang menandakan baik buruknya sesuatu. Menurut Veithzal dan Deddy (Mulyadi \& Rivai, 2012) "Quality is any feature that distinguishes or identifies someone or something". Kualitas adalah suatu ciri yang membedakan seseorang atau sesuatu. Dari uraian diatas 
dapat disimpulkan bahwa kualitas adalah mutu sesuatu atas suatu pekerjaan yang merupakan ciri yang membedakannya dengan yang lain serta dapat menentukan tingkat penyesuaiannya terhadap spesifikasinya. Sedangkan defenisi tenaga kerja menurut undang-undang Nomor 13 Tahun 2003 Tenaga kerja adalah orang yang mampu melakukan pekerjaan guna menghasilkan barang dan jasa dalam memenuhi kebutuhan sendiri maupun kebutuhan orang banyak.

Menurut Simanjuntak (1998) dalam Oktaviana (2011:9), tenaga kerja merupakan sejumlah penduduk yang sudah bekerja atau sedang bekerja, yang sedang mencari pekerjaan dan yang melakukan kegiatan lain seperti sekolah dan mengurus rumah tangga yang walaupun tidak bekerja, tetapi mereka secara fisik mampu untuk bekerja. Berdasarkan uraian diatas dapat disimpulkan bahwa tenaga kerja adalah penduduk yang berusia 15 sampai 64 tahun baik yang sudah bekerja, sedang bekerja maupun yang sedang mencari kerja yang mampu melakukan pekerjaan guna menghasilkan barang dan jasa untuk memenuhi kebutuhan. Dari uraian diatas dapat disimpulkan bahwa kualitas tenaga kerja adalah mutu tenaga kerja atas sesuatu yang merupakan ciri yang membedakannya dengan yang lain serta dapat menentukan tingkat penyesuaian tenaga kerja terhadap spesifikasinya.

\section{Konsep Faktor-faktor yang Mempengaruhi Efektivitas}

Adapun faktor-faktor yang mempengaruhi efektivitas suatu organasasi menurut Richard M Steers (1985:9) dalam Rusli Isa (Isa, 2009) adalah sebagai berikut:

\section{1) Karakteristik organisasi}

Dalam organisasi terdapat suatu hubungan yang memiliki sifat yang relative tetap, dimana organisasi terdiri dari susunan beberapa sumber daya manusia yang ditempatkan pada posisi tertentu dalam melakukan pekerjaan dengan berorientasi pada tugas dalam upaya mencapai tujuan organisasi tersebut.

2) Karakteristik lingkungan

Lingkungan terdiri dari dua aspek, aspek pertama adalah lingkungan ekstern yaitu lingkungan yang berada di luar organisasi. Lingkungan ekstern ini memiliki pengaruh yang besar terhadap kelancaran pencapaian tujuan organisasi.Selanjutnya aspek kedua adalah lingkungan intern yaitu lingkungan yang berasal dari dalamorganisasi itu sendiri. Lingkungan intern ini merupakan kunci dari pelaksanaan pencapaian tujuan suatu organisasi, dimana tujuan organisasi akan tercapai apabila didalam organisasi tersebut terdapat iklim kerja yang berorientasi pada tujuan utama organisasi itu sendiri.

\section{3) Karakteristik pekerja}

Karakteristik pekerja dalam suatu organisasi merupakan faktor penentu dalam keberhasilan pencapaian tujuan organisasi. Dalam diri setiap individu akan ditemukan banyak perbedaan, oleh karena itu perlu adanya kesadaran setiap individu akan perbedaan tersebut sehingga proses pencapaian tujuan organisasi tidak terhalangi oleh perbedaan ini.

4) Kebijakan dan praktik manajemen.

Praktik manajemen merupakan mekanisme kerja yang dirancang untuk mencapai tujuan organisasi. Kebijakan dan praktek manajemen merupakan media bagi pimpinan untuk mengarahkan setiap kegiatan yang dilakukan agar tetap berorientasi pada tujuan organisasi.

\section{METODE PENELITIAN}

Penelitian yang penulis gunakan merupakan jenis penelitian kualitatif dengan memakai metode deskriptif. Kegiatan penelitian dilaksanakan pada Kantor UPTD BLK Kabupaten Padang Pariaman.Kegiatan penelitian ini dilaksanakan dalam kurun waktu sekitar 3 (tiga) bulan. Untuk menentukaninforman, penulis menggunakan metode purposive sampling yaitu pemilihaninforman dengan 
berdasarkan pada kriteria yang dimiliki oleh orang tersebut yang sesuai dengan tujuan penelitian. Informandalam penelitian ini yaitu Kepala Sub Bagian Tata Usaha (Kasubag TU) UPTDBLK Kabupaten Padang Pariaman, InstrukturPelatihan Kerja UPTD BLK Kabupaten Padang Pariaman,Peserta lulusan pelatihan kerja UPTD BLK Kabupaten Padang Pariaman, dan Indsutri atau tempat kerja lulusan peserta pelatihan. Teknik pengumpulan data dilakukan dengan cara observasi, wawancara dan studi dokumentasi. Sedangkan untuk menganalisis data dilakukan dengan cara mereduksi data, kemudian penyajian data, serta verifikasi data. Selanjutnya uji keabsahan data menggunakan teknik triangulasi sumber.

\section{HASIL DAN PEMBAHASAN}

\section{Efektivitas UPTD BLK Kabupaten Padang Pariaman}

1) Adanya kejelasan tujuan yang akan dicapai

Berdasakan penelitian yang telah dilakukan pada UPTD Balai Latihan Kerja (BLK) Kabupaten Padang Pariaman, peneliti melihat telah adanya kejelasan tujuan yang hendak dicapai oleh UPTD BLK ini, yaitu bertujuan untuk meningkatkan kualitas tenaga kerja, dimana tenaga kerja memiliki kompetensi dalam bidang tertentu yang dapat dijadikan bekal untuk memasuki pasar kerja atau industry maupun berwirausaha sendiri. Pencapaian tujuan ini dapat dilihat dari hasil kompetensi yang dilakukan oleh peserta pelatihan, yang mana dari hasil ini peserta pelatihan mengalami peningkatan kualitas yang cukup baik. Selain itu pencapaian tujuan juga dapat dilihat dari pernyataan peserta pelatihan lulusan UPTD BLK yang mengatakan bahwa mereka mengalami peningkatan pengetahuan dan keterampilan setelah mengikuti pelatihan kerja pada UPTD BLK. Kemudian pencapaian tujuan juga dilihat dari pernyataan pihak industry tempat peserta lulusan UPTD BLK bekerja yang mengatakan bahwa lulusan UPTD
BLK memiliki kualitas kerja yang bagus, dimana mereka lebih terampil dibanding karyawan lainnya yang tidak mengikuti pelatihan sebelumnya.

2) Adanya kejelasan strategi dalam upaya mencapai tujuan

Agar dapat meningkatkan kualitas tenaga kerja UPTD BLK memiliki strategi yaitu dengan melakukan pelatihan kerja yang sesuai dengan standar pelatihan kerja dan dilakukan oleh instruktur pelatihan yang berkompeten dibidangnya.

3) Melakukan analisa dan perumusan kebijaksanaan yang mantap

Dalam rangka mencapai tujuan, UPTD BLK membuat kebijaksanaankebijaksanaan yang berkaitan dengan pelatihan yaitu seperti membuat Rencana Pelaksanaan Kegiatan (RENLAKGIAT) Pelatihan, kemudian membuat kebijaksanaan-kebijaksanaan untuk mengatasi kendala yang terdapat pada UPTD BLK seperti kendala kurangnya instruktur, BLK membuat keijksanaan dengan cara meminta bantuan kepada instruktur swasta dan instruktur yang sudah pensiun untuk melakukan pelatihan dan untu permasalahan kurangnya sarana pelatihan BLK membuat kebijaksanan dengan cara mengubah metode pengajaran dan menyewa peralatan pelatihan dari pihak luar atau swasta. Sehingga dengan adanya kebijaksanaan ini kegiatan pelatihan kerja dapat tetap terlaksana.

4) Membuat perencanaan yang matang

UPTD BLK juga memiliki memiliki perencanan yang matang yaitu dengan membuat RENLAKGIAT Pelatihan setia tahunnya, dimana dalam RENLAKGIAT Pelatihan ini dibuat perencanan program pelatihan yang akan dilakukan, jangka waktu pelaksanaan rekrutmen peserta pelatihan, jangka waktu pelaksanaan pelatihan, jumlah paket pelatihan, dan jenis pelatihan yang akan dilakukanapakah pelatihan yang dilakukan di kantor UPTD BLK (Institusional) atau pelatihan yang 
dilakukan di daerah-daerah (Non Institusional).

5) Menyusun program secara tepat

UPTD BLK melakukan penyusunan program pelatihan kerja dengan berdasarkan pada minat calon peserta pelatihan dan berdasarkan Training Need Analysis (TNA) yang dilakukan dengan industry yang akan menggunakan jasa lulusan UPTD BLK.Training Need Analysis (TNA) ini dilakukan dengan cara membagikan kusioner atau wawancara pada industri, sehingga dapat diketahui kebutuhan tenaga kerja di industri tersebut.

\section{6) Menyediakan sarana dan prasarana kerja}

Dalam melaksanakan program pelatihan kerja, UPTD BLK menyediakan sarana dan prasarana pelatihan seperti bahan pelatihan, peralatan pelatihan, workshop pelatihan, gudang penyimpanan barang dan lain-lain. Hanya saja sarana dan prasarana yang terdapat pada UPTD BLK masih kurang memadai, hal ini dapat dilihat dari sarana pelatihan yang terdapat pada masingmasing kejuruan yang mengalami kerusakan, baik kerusakan dalam kategori ringan, sedang, maupun berat. Selanjutnya masih terdapat kekurangan sarana pelatihan pada beberapa kejuruan dan sub kejuruan.

7) Pelaksanaan yang bersifat efektif dan efisien

UPTD BLK melaksanakan program pelatihan kerja dengan efektif dan efisien, dimana pelatihan kerja dilakukan dengan tahapan-tahapan yang jelas yaitu mulai dari pembukaan pelatihan, pelaksanaan pelatihan, penutupan pelatihan, dan proses monitoring dan evaluasi.

\section{8) Melakukan pengawasan dan pengendalian yang bersifat mendidik}

UPTD BLK melakukan pengawasan dalam bentuk monitoring yang dilakukan dengan 2 (dua) tahap yaitu pada saat pelaksanaan pelatihan kerja dan setelah pelatihan kerja. Pelaksanaan monitoring pada saat pelaksanaan pelatihan bertujuan untuk mengetahui apakah peserta pelatihan sudah terlayani oleh instruktur pelatihan. Sedangkan pelaksanaan monitoring yang dilakukan pada saat sesudah pelatihan bertujuan untuk melihat bagaimana perkembangan peserta setelah mengikuti pelatihan.

\section{Faktor-faktor yang mempengaruhi keefektifan UPTD BLK Kabupaten Padang Pariaman}

1) Karakteristik organisasi

UPTD BLK memiliki struktur organisasi terdiri dari susunan beberapa sumber daya manusia yang ditempatkan pada posisi tertentu dalam melakukan pekerjaan desngan berorientasi pada tugas dalam upaya mencapai tujuan UPTD BLK Kabupaten Padang Pariaman ini. Seperti Kepala UPTD bertugas menjalankan tugas dan fungsi UPTD BLK. Kemudian Kasubag TU bertugas megelola urusan administrasi, tata usaha dan lain-lain. Kemudian pejabat fungsional yang melaksanakan kegiatan sesuai dengan bidangnya seperti instruktur, memiliki tugas melaksanakan pelatihan sesuai dengan bidang keahliannya.

\section{2) Karakteristik lingkungan}

Karaktersitik lingkungan terdiri dari 2 (dua) aspek yaitu aspek lingkungan internal yang merupakan aspek lingkungan yang berasal dari dalam UPTD BLK itu sendiri dan aspek lingkungan eksternal yaitu aspek dari luar UPTD BLK, aspek eksternal seperti masyarakatmemiliki pernanan yang sangat penting dalam pelaksanaan pelatihan pada UPTD BLK, karena apabila tidak ada kontribusi masyarakat dalam pelaksanaan pelatihan pada UPTD BLK ini maka tujuan UPTD BLK untuk meningkatkan kualitas tenaga kerja tidak akan tercapai. Sejauh ini kedua aspek ini dapat berkontribusi dengan baik, contohnya saja pada tahun ini UPTD BLK membuka sub kejuruan baru yaitu sub kejuruan pembuat roti dan kue, dan ternyata sub kejuruan ini menarik minat masyarakat untuk mengikuti pelatihan, dimana terdapat sekitar 100 orang lebih yang mendaftar, sedangkan UPTD BLK hanya merekrut peserta pelatihan sebanyak 16 orang. 
3) Karakterisik pekerja

Karakeristik pekerja memberikan pengaruh yang besar terhadap keberhasilan pencapaian tujuan UPTD BLK. Setiap pekerja atau pegawai memiliki karakteristik yang berbeda-beda, namun dengan adanya kesadaran mereka akan perbedaan tersebut proses pencapian tujuan UPTD BLK tetap dapat terlaksana.

4) Kebijakan dan praktik manajemen

Kebijakan dan praktik manajemen merupakan faktor penentu dalam pencapaian tujuan UPTD BLK. Dalam melakukan kebijaka dan praktik manajemen UPTD BLK berorientasi pada tujuan utama yaitu meningkatkan kualitas tenaga kerja. UPTD BLK juga melakukan mekanisme kerja yang jelas yaitu dengan melakukan kegiatan pelatihan dengan mengikuti alur pelatihan yang telah ditetapkan, selain itu dalam melakukan kegiatan pelatihan UPTD BLK mengacu kepada standar pelatihan yang telah ditetapkan yaitu standar pelatihan kerja nasional, UPTD BLK juga memiliki tujuan yang jelas yaitu untuk meningkatkan kualitas tenaga kerja, UPTD BLK juga dapat dapat memanfaatkan sumber daya manusia yang terdapat dalam UPTD BLK itu sendiri seperti instruktur, UPTD BLK dapat memanfaatkan instruktur pelatihan semaksimal mungkin sesuai dengan bidang keahlian yang dimilikinya, serta UPTD BLK mampu menciptakan lingkungan yang berprestasi yaitu dengan meningkatkan kualitas tenaga kerja.

\section{PENUTUP}

Setelah dilakukan pembahasan mengenai data-data yang penulis peroleh selama melakukan penelitian, penulis akan menarik kesimpulan dan saran. Adapun kesimpulan yang didapat dari penelitian tersebut adalah UPTD BLK Kabupaten Padang Pariaman cukup efektif dalam upaya meningkatkan kualitas tenaga kerja karena selaras dengan indikator efektivitas, UPTD BLK memiliki kejelasan tujuan yang akan dicapai, memiliki kejelasan strategi dalam upaya mencapai tujuan, melakukan analisa dan perumusan kebijaksanaan yang mantap, membuat perencanaan yang matang, menyusun program secara tepat, menyediakan sarana dan prasarana kerja, pelaksanaan yang bersifat efektif dan efisien, dan melakukan pengawasan dan pengendalian yang bersifat mendidik. Selanjutnya faktor - faktor yang mempengaruhi keefektifan UPTD BLK Kabupaten Padang Pariaman juga selaras dengan faktor-faktor yang mempengaruhi efektivitas yaitu karakteristik organisasi, karakteristik lingkungan, karakteristik pekerja, serta kebijakan dan praktik manajemen.

\section{DAFTAR KEPUSTAKAAN}

Ritno H. Rondonuwu, J. J. (2015). Analisis Efisiensi dan Efektivitas Pengelolaan Keuangan Daerah Pada Dinas Pendapatan Daerah Kabupaten Minahasa. Jurnal Emba, Vol.3 No.4 hal. 23-32.

Dedy Mulyadi dan Veithzal Rivai. (2012). Kepemimpinan dan perilaku organisasi. Jakarta: Rajagrafindo Persada.

Fathoni, Abdurrahmat. (2006). Organisasi dan Manajemen pada Sumber Daya Manusia. Jakarta: Rineka Cipta.

Isa, Rusli. (2009). Efektivitas Organisasi Kecamatan Dalam Pelayanan Publik Setelah Menjadi Peragkat Daerah.Inovasi, hal 70-86.

Saputri, Oktaviana. Dwi. (2011). Analisis Penyerapan Tenaga Kerja di Kota Salatiga. Skripsi. Universitas Diponegoro, hal 1-70.

Siagian, Sondang. P. (1984). Management Modern. Jakarta: Gunung Agung.

Peraturan Perundang-undangan Republik Indonesia No.13 Tahun 2003 mengenaiKetenagakerjaan. 
Fahrani Yulzain, Jumiatil Efektivitas UPTD Balai Latihan Kerja (BLK) dalam Meningkatkan Kualitas Tenaga Kerja di UPTD BLK Kabupaten Padang Pariaman

Kementerian Tenaga Kerja Republik Indonesia No. 8 Tahun 2017 mengenai Standar Balai Latihan Kerja.

Perbup Padang Pariaman No. 47 Tahun 2017 Tentang Unit Pelaksana Teknis Daerah pada Dinas Perdagangan, Tenaga Kerja Koperasi dan Usaha Kecil Menengah.
Peraturan Menteri Dalam Negeri No. 12 Tahun 2017 Tentang Pembentukan dan Cabang Dinas dan Unit Pelaksana Teknis Daerah.

Widodo, Suparno. Eko. (2018). Manajemen Pelatihan. Jakarta: Pustaka Pelajar. 